\title{
Retters to the Editor
}

To The Editor, Rangelands

The View Points article in the April 2005 Rangelands entitled "Range Readiness Is an Obsolete Management Tool" intrigued me. I have a few reservations about their thesis.

They infer the range readiness concept is outdated and without foundation in today's world. They claim that if there is enough forage to maintain animal condition and if soils are firm enough to adequately support consequent treading, we need not be concerned with vegetative readiness at all.

I have no problem dropping this rule of thumb on most rangelands in semiarid climates of western North America where we have had a century of learning experience and even some good supporting science. But when one considers other rangelands in today's world, like tropical and subtropical or alpine and subalpine ranges in third-world countries, it may not be a good recommendation. For example, in Tibet, Zambia, or Bolivia, where they still don't have fences, four-wheelers, or range management institutions, vegetative guidelines may still be of value in reaching herdsmen.

On another score, these authors made a point of saying early researchers who developed the readiness concept were only concerned with vegetative range readiness and had no understanding of soil conditions relative to range readiness. They cited A. W. Sampson and others. WHOA! In 1907, Dr Sampson set up grazing experiments in the high mountains of northeastern Oregon with weather stations for measuring soil moisture, evapotranspiration, humidity, and temperatures. The Wallowa Sun (Wallowa, Oregon) said on June 7, 1911, that Arthur Sampson had just arrived from Washington, D.C. and was soon to be joined by Mr [Dr Wm. O.] Dayton and Mr Baston, who would be studying soils of that high mountain sheep range.

In 1913, when Sampson wrote up his results in USDA Circular 169 "Range Improvement by Deferred and Rotation Grazing," he wasn't just considering vegetation development. The same year he initiated paired watersheds on the Wasatch Plateau to study infiltration and soil erosion. Therefore, to say early researchers did not consider soil conditions relative to range readiness is faulty.

Fredric Colville studied sheep grazing in the forests of the Cascade Mountains of Oregon in the late 1890s and discovered that if forage development was not far in excess of that needed to maintain animal condition, destructive grazing on conifer regeneration occurred. This is an example of the use of vegetative development practices as fitting today as it was over a century ago. Moreover, vegetative range readiness indicators are useful in establishing livestock "turn-on" dates for manipulating conservation status in critical wildlife habitats.

All this implies to me that total rejection of old concepts is problematical and should be tempered with moderation. I suggest we not throw the baby out with the bath water.

Jon M. Skovlin 